\title{
Value Priorites of Teacher Candidates: Using a Scaling Technique for Value Ranking
}

\begin{tabular}{ccc}
\hline Article Type & Received Date & Accepted Date \\
Research & 14.11 .2019 & 17.01 .2020 \\
\hline
\end{tabular}

\section{Cengiz Aslan*}

\begin{abstract}
Values which may be defined differently in various disciplines are the main determinants of decision making process for people. In this framework teachers, as one of the most fundamental actor of formal education institution, and their values will be the determinant of the quality for teaching-learning process and products. The purpose of this research is to determine the value priorities of teacher candidates in Turkey. Rokeach Value Survey (RVS) was used as a data collection tool. The rank order judgements scaling technique was used in order to analyze the research data. In this technique, it is determined that how a person prioritizes values rather than whether a value is possessed by the person. The RVS consists of two alphabetically ordered lists of 18 values as terminal and instrumental values. When the terminal values in RVS are analyzed using the scaling technique based on ranking judgments, the most commonly (predominantly) preferred value by teacher candidates is "family security", while the least commonly preferred terminal value is "pleasure". Among the instrumental values in the RVS, the most commonly (predominantly) preferred value is the "honesty", while the least commonly preferred one is the "obedience".
\end{abstract}

Keywords: Values, Rokeach Value Survey (RVS), scaling, ranking, teacher candidate.

\footnotetext{
* Corresponding Author: Dr.,Ankara University, Faculty of Educational Sciences, Department of Educational Sciences, Ankara, Turkey. E-mail:cngzaslan@gmail.com, https://orcid.org/ 0000-0003-3710-9838
} 


\section{Öğretmen Adaylarının Değer Önceliklerinin Sıralama Yargılarına Dayalı Ölçekleme Tekniği Kullanılarak Belirlenmesi}

\begin{tabular}{ccc}
\hline $\begin{array}{c}\text { Makale Türü } \\
\text { Araştırma }\end{array}$ & $\begin{array}{c}\text { Başvuru Tarihi } \\
14.11 .2019\end{array}$ & $\begin{array}{c}\text { Kabul Tarihi } \\
17.01 .2020\end{array}$ \\
\hline & & \\
& Cengiz Aslan* & \\
& Öz
\end{tabular}

Çeşitli disiplinler açısından farklı tanımlanan değerler, bireylerin günlük yaşamda aldıkları kararların belirleyicisi konumundadır. Bu çerçevede formal eğitim kurumlarının en temel aktörü olan öğretmenlerin sahip olduğu değerlerin, eğitim-öğretim süreç ve ürünlerinin niteliğinin belirleyicisi olduğu söylenebilir. Araştırmanın amacı öğretmen adaylarının değer önceliklerinin belirlenmesidir. Bu araştırma, öğretmen adaylarının değer önceliklerini ortaya koymaya çalışan betimsel tarama modelinde bir araştırmadır. Araştırmada veri toplama aracı olarak Rokeach Değer Envanteri kullanılmıştır. Araştırma verilerinin analizi sıralama yargılarına dayalı ölçekleme tekniği ile yapılmıştır. Bu yöntemle bir değerin kişide varolup olmamasından çok, kişinin bu değerleri nasıl öncelediği belirlenmektedir. Envanter, alfabetik olarak sıralanmış 18'er adet amaçsal ve araçsal değer listesinden oluşmaktadır. Envanterde yer alan amaçsal değerler sıralama yargılarına dayalı ölçekleme tekniği kullanılarak analiz edildiğinde, öğretmen adayları tarafından en çok (ağırlıklı) öncelikli tercih edilen amaçsal değer "aile güvenliği" değeri, en az tercih edilen amaçsal değer "zevk" değeridir. Envanterde yer alan araçsal değerlerden öncelikli tercih edilen araçsal değer "dürüstlük" değeri, en az tercih edilen araçsal değer ise "itaatkârlık" değeridir.

Anahtar Sözcükler: Değerler, Rokeach Değer Envanteri, ölçekleme, sıralama, öğretmen adayı.

\footnotetext{
* Sorumlu Yazar: Dr., Ankara Üniversitesi, Eğitim Bilimleri Fakültesi, Eğitim Bilimleri Bölümü, Ankara, Türkiye. E-posta:cngzaslan@gmail.com, https://orcid.org/ 0000-0003-3710-9838
} 


\section{Introduction}

Various disciplines are closely interested in values as a concept. In sociology 'values' are defined as culturally defined standards that people use when deciding what is appealing, beautiful and good as well as general principles that are the key to social life and support beliefs (Macionis, 2012). In philosophy, values viewed as evaluation of objects in the outside world so as to exhibit the positive or negative meanings that they bear for people and the society in a way that is societally accepted (Çalışlar, 1997). In psychology 'values' are defined as a product of a mental process (Akyıldız, 2018). According to Kuşdil and Kağıtçıbaşı (2000), this cross-disciplinary interest arises from the fact that social scientists view values as bearing a fundamental significance in explaining human behaviour. Along with this, according to Boudon (2013), the origin of values from the perspective of social scientists is a complicated issue. Within this frame, it can be said that the differences in the definitions of the phenomenon with regard to various disciplines is both related to the phenomenon itself and its origin.

According to Rokeach (1973), there are five assumptions regarding values as abstract and general principles that govern the behavioural patterns in a certain culture. The five principles are: values that people have are limited; all people exhibit the same values at different levels everywhere; values occupy value systems; the origin of human values are found within cultures, societies, institutions and personality structures; the results of human values are reflected on all the social processes that social scientists too endeavour to understand and study. Within the frame of these assumptions, values which are perceived by each individual for their own in the societal life and compared with one another can be defined each as a criterion (Tolan, 2005) which aids in arriving at judgments such as good-bad, right-wrong, important-trivial. In other words, values are the shared criteria or ideas that put forth which societal behaviour is good, right and desirable (Özkalp, 2005). According to Tasker and Packham (1993), values have a more personal meaning which is derived from what is of value and gives purpose to individuals or groups. Therefore, it can be said that people who share a culture make decisions regarding how they are to live using values (Macionis, 2012) and that our choices in the daily life are fraught with the influence of values. With reference to all of these definitions, it can be acknowledged that values are each a criterion in the thoughts, attitudes and work of individuals. Rokeach (1973) states that values have cognitive, affective and behavioural components; and that when we say that a person has a value, what will be understood is the beliefs concerning the desired behavioural patterns or desired existence conditions. Therefore, it can be said that these definitions and assumptions put forth the fact that values are cultural, societal, individual and periodical, that it is a problematic subject area as well as corresponding to their changeability. On this subject, Rokeach (1973) states that the differences in culture, social classes, professions, religions or political preferences are related to individuals' values and value systems. Values are gained through socialization process and individuals constitute their own definitive value system, exhibiting social behaviour that is a product of this value system. According to Ning, Lee and Lee (2015), individuals' actions and behaviours are shaped by the underlying system of values'. Within this frame, it can be said that value system as a behaviour takes shape so as to meet the need of selfness of the individual and as a product of his/her learnings. Individuals in the socialization process both acquire the behaviours approved by the societal structure and meet their needs of personality (Akyıldiz \& Aslan, 2016). According to Maslow (1970) if the individual meets their need of self-respect, it will lead them to have the emotions of confidence, value, power, skill as well as competence providing the feeling of usefulness and necessity for the world. In the case that the meeting of these needs is hindered, the emotions of inferiority, weakness and desperation will emerge. Rokeach (1973) states that if values are acknowledged as cognitive indicators of needs, the differentiation in values actually should show the differentiation in needs; and that values and needs are meaningfully related to one another.

The mental-emotional disposition of the individual, according to Aky1ldiz and Aslan (2016), defines themselves as a product of the characteristics they have and reaches its potential as a result of the environmental structure proving suitable. The environmental structure that the individual resides in is their informal-formal educational environment. If the education service helps the individual for gaining new behavior, the individual who will design the new behavior should form a new mentalemotional structure in their own terms. Within this frame, the general aim of education is to provide individual with behaviors that will aid them in leading an actively fulfilling life. The experiences of teaching practice, on the other hand, serves the teacher candidate in forming behaviors regarding how they are to maintain teaching. According to Smith and Schwartz (1996) the value priorities prevalent 
in a society are a key element, perhaps the most central, in its culture, and individuals represent central goals that relate to all aspects of behavior. On the other hand, values are directly influenced by everyday experiences in changing ecological and sociopolitical contexts. Values are therefore wellsuited for examining the ongoing processes of cultural and individual change in response to historical and social changes". Therefore, examining the value priorities of individual will provide information for historical social and cultural changes in Turkish society. Within this frame, the research problem is to determine the value priorities of teacher candidates in different teacher training programs in Turkey.

\section{Method}

The aim of the study was to determine the value priorities of the teacher candidates by using ranking judgements scaling technique. It is important to know the value priorities of teachers who are the fundamental actors of formal educational environments. Besides this, using the scaling technique in educational research will provide fruitful data. This study was a descriptive survey model study that attempts to reveal the value priorities of teacher candidates in Turkey. According to Karasar (2003), the aim of the survey studies, which are prevalently used in social sciences, is to describe a state of affairs that existed in the past or is still extant. The event, individual or object that becomes the subject of the research is endeavored to be defined in its own conditions and as it actually is. According to Neuman (2010), researcher starts with a theoretical or a practical research problem and finalizes the survey with empirical measurements and data analysis.

\section{Participants}

In this research, the study group was teacher candidates in two different public universities in Ankara and Denizli. In these universities, teacher candidates enrolled in the Pedagogic Formation Training Programs were informed about the research and data collected from the valuntary participants. 200 teacher candidates in the Pedagogic Formation Training Programs in the departments of philosophy $(f=51)$, theology $(f=76)$ and sociology $(f=73)$ were participated in the study. 157 of the participants were female and 43 of them were male while 175 of them were single and 25 of them married.

\section{Research Instruments and Procedures}

Rokeach Value Survey (RVS) (1973) was used as a data collection tool. It has been ascertained that RVS, the validity and reliability tests of which were done by Aslan and Çalışkur (2013), can measure values on terminal and instrumental dimensions. All of the values in the RVS are socially accepted values and they are functionally related. Concerning the nature of values, Rokeach (1973) classified them terminally and instrumentally (Table 1), stating that they exhibit consistency, are a belief and are related with behavior pattern or appraisal of existence. He states that these two value groups embody different roles in different areas of social life. Terminal values are distinguished into two types as personal and social; while instrumental values are distinguished into two types as moral and competence related. He states that, terminal values are self-centered or society-centered. While the focus of self-centered values is oriented towards the person herself and her essence, societycentered values are extroverted and oriented towards others. Within this frame, people's values, attitudes and behaviors change according to what they give primacy to the personal or societal values. Moral values among instrumental values are rather limited in terms of general values and are about the manner of behavior. Competence, as another terminal value concerns self-actualization and rather personal instead of interpersonal and it does not have to be moral. The violation or non-possession of this value ends up with feeling of personal inadequacy instead of feeling guilty or the feeling of having done wrong as in the moral value. Thus, behaving honestly and responsibility leads one to feel that he is behaving morally, whereas behaving logically, intelligent or imaginatively leads one to feel that he is behaving competently (Rokeach, 1973). Within this frame, terminal values exhibit the individuals' fundamental goals in their lives, while instrumental values exhibit how they want to reach the goals that they pursue (Kuşdil and Kağıtçıbaşı, 2000). 


\section{Table 1}

List of Terminal and Instrumental Values

\begin{tabular}{|c|c|c|c|}
\hline \multicolumn{2}{|c|}{ Terminal values } & \multicolumn{2}{|c|}{ Instrumental values } \\
\hline $\begin{array}{c}\text { Social } \\
\text { (society-centered) }\end{array}$ & $\begin{array}{c}\text { Personal } \\
\text { (self-centered) }\end{array}$ & $\begin{array}{c}\text { Moral } \\
\text { (focus on morality and } \\
\text { relations) }\end{array}$ & $\begin{array}{c}\text { Competence } \\
\text { (self actualization) }\end{array}$ \\
\hline $\begin{array}{l}\text { Family security } \\
\text { (taking care of loved ones) }\end{array}$ & $\begin{array}{l}\text { Salvation } \\
\text { (saved, eternal life) }\end{array}$ & $\begin{array}{l}\text { Responsible } \\
\text { (dependable, reliable) }\end{array}$ & $\begin{array}{l}\text { Capable } \\
\text { (competent, effective) }\end{array}$ \\
\hline $\begin{array}{l}\text { A world at peace } \\
\text { (free of war and conflict) }\end{array}$ & $\begin{array}{l}\text { A sense of } \\
\text { accomplishment } \\
\text { (a lasting contribution) }\end{array}$ & $\begin{array}{l}\text { Honest } \\
\text { (sincere, truthful) }\end{array}$ & $\begin{array}{l}\text { Courageous (standing up } \\
\text { for your beliefs) }\end{array}$ \\
\hline $\begin{array}{l}\text { Equality (brotherhod,egual } \\
\text { opportunity for all) }\end{array}$ & $\begin{array}{l}\text { Wisdom (a mature } \\
\text { understanding of life) }\end{array}$ & $\begin{array}{l}\text { Obedient } \\
\text { (dutiful,respectful) }\end{array}$ & $\begin{array}{l}\text { Imaginative } \\
\text { (daring,creative) }\end{array}$ \\
\hline $\begin{array}{l}\text { True friendship } \\
\text { (close companionship) }\end{array}$ & $\begin{array}{l}\text { An exciting life (a } \\
\text { stimulating, active life) }\end{array}$ & $\begin{array}{l}\text { Loving } \\
\text { (affectionate,tender) }\end{array}$ & $\begin{array}{l}\text { Logical } \\
\text { (consistent,rational) }\end{array}$ \\
\hline $\begin{array}{l}\text { A world of beauty } \\
\text { (beauty of nature and the } \\
\text { arts) }\end{array}$ & $\begin{array}{l}\text { Inner harmony(freedom } \\
\text { from inner conflict) }\end{array}$ & $\begin{array}{l}\text { Polite (courteous, well } \\
\text { mannered) }\end{array}$ & $\begin{array}{l}\text { Ambitious } \\
\text { (hard-working, aspiring) }\end{array}$ \\
\hline $\begin{array}{l}\text { Mature love (sexual and } \\
\text { spiritual intimacy) }\end{array}$ & $\begin{array}{l}\text { Self-respect } \\
\text { (self-esteem) }\end{array}$ & $\begin{array}{l}\text { Helpful (working for } \\
\text { the welfare of others) }\end{array}$ & $\begin{array}{l}\text { Clean } \\
\text { (neat, tidy) }\end{array}$ \\
\hline $\begin{array}{l}\text { Social recognition } \\
\text { (respect, admiration) }\end{array}$ & $\begin{array}{l}\text { Happiness } \\
\text { (contentedness) }\end{array}$ & $\begin{array}{l}\text { Forgiving (willing to } \\
\text { pardon others) }\end{array}$ & $\begin{array}{l}\text { Independent (self-reliant, } \\
\text { self-sufficient) }\end{array}$ \\
\hline $\begin{array}{l}\text { Freedom } \\
\text { (independence,free choice) }\end{array}$ & $\begin{array}{l}\text { A comfortable life } \\
\text { (a prosperous life) }\end{array}$ & $\begin{array}{l}\text { Cheerful } \\
\text { (lighthearted, joyful) }\end{array}$ & $\begin{array}{l}\text { Self-Controlled } \\
\text { (restrained,self- } \\
\text { discipline) }\end{array}$ \\
\hline $\begin{array}{l}\text { National security } \\
\text { (protection from attack) }\end{array}$ & $\begin{array}{l}\text { Pleasure (an enjoyable } \\
\text { leisurely life) }\end{array}$ & $\begin{array}{l}\text { Broadminded } \\
\text { (open-minded) }\end{array}$ & $\begin{array}{l}\text { Intellectual (intelligent, } \\
\text { reflective) }\end{array}$ \\
\hline
\end{tabular}

\section{Data Analysis}

The rank order judgments scaling technique was used in the analysis of the data. According to Turgut and Baykul (1992), in this technique, which can be applied to all stimulants, that can be given a ranking number, all of the stimulants are given to the observants together in order for them to rank them in ascending or descending order. Proving the meaningful measurement and comparison of objects according to Dunn-Runkin et al. (2004), the main aim of the scaling is to measure and compare the objects in a meaningful way. As for Anıl and Güler (2006) it is put forth the basic rules and primary methods of the transition from observations to measurements.

In order to collect teacher candidates' judgments on values, they were asked to give a ranking number to each value in the RVS according to their own priorities. Rokeach (1973) stated that the values being in alphabetical order can lead to misguidance due to responders thinking that certain values are of higher priority. He defines this state of affairs as ranking effect. In order to neutralize this effect, respondents were asked to rank initially the first five and the last five values and then the rest of the values in terms of their priority in the Turkish form of the scale. Since the individuals assign the smallest number to the value of highest priority to them, the smaller numerical values in the scale illustrate the value that is given higher priority. SPSS 22 and excel programs have been used in the analysis of the data. As a result of the process which was made by using rank order judgements scaling technique, a frequency matrix has been created determining the frequency of values ranked by the participants. According to Guilford (1954), each column in the frequency matrix represents a stimulus, each line represents an observer and each cell represents a ranking given to a specific stimulant by a specific observant. The ratio matrix was acquired by dividing the values in each cell of the frequency matrix to the total number of people. The $z$ values that are correspondent to the elements of ratio matrix were identified and the unit normal variance matrix was created. The mean of each $z$ value across the columns was calculated and then, the scale values were found. Teacher candidates' most preferential values were determined by this technique. 


\section{Findings}

Teacher candidates' responses to the RVS and analysis of their responses with scaling technique were given in the following tables.

Table 2

Terminal Values Frequency Matrix

\begin{tabular}{|c|c|c|c|c|c|c|c|c|c|c|c|c|c|c|c|c|c|c|c|}
\hline & 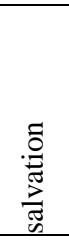 & 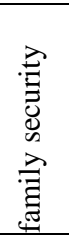 & 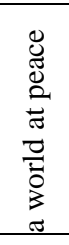 & $\begin{array}{l} \\
+ \\
0 \\
0 \\
0 \\
0 \\
\infty \\
\approx\end{array}$ & $\begin{array}{l}\tilde{z} \\
\tilde{0} \\
\frac{m}{3} \\
3\end{array}$ & 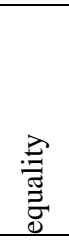 & 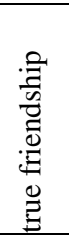 & 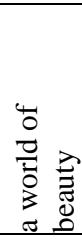 & 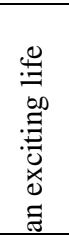 & 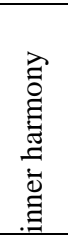 & 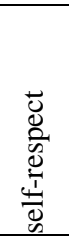 & 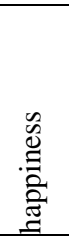 & 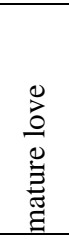 & 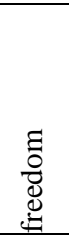 & 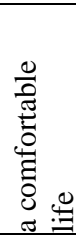 & 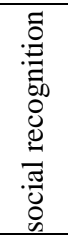 & 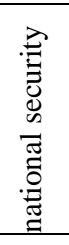 & 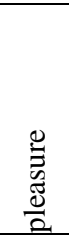 & $\stackrel{\overrightarrow{0}}{0}$ \\
\hline 1 & 81 & 25 & 24 & 1 & 7 & 3 & 2 & 1 & 2 & 15 & 11 & 6 & 0 & 13 & 2 & 1 & 4 & 2 & 200 \\
\hline 2 & 21 & 54 & 23 & 11 & 15 & 8 & 4 & 1 & 2 & 16 & 10 & 11 & 1 & 10 & 2 & 3 & 7 & 1 & 200 \\
\hline 3 & 11 & 23 & 32 & 12 & 4 & 17 & 12 & 4 & 2 & 18 & 16 & 15 & 4 & 10 & 7 & 0 & 12 & 1 & 200 \\
\hline 4 & 2 & 23 & 16 & 14 & 11 & 18 & 10 & 5 & 6 & 19 & 22 & 15 & 3 & 16 & 6 & 1 & 11 & 2 & 200 \\
\hline 5 & 4 & 16 & 14 & 14 & 14 & 14 & 17 & 3 & 6 & 15 & 15 & 14 & 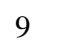 & 23 & 9 & 2 & 9 & 2 & 200 \\
\hline 6 & 7 & 18 & 10 & 15 & 7 & 24 & 17 & 4 & 8 & 16 & 13 & 9 & 6 & 14 & 9 & 7 & 10 & 6 & 200 \\
\hline 7 & 8 & 10 & 15 & 16 & 11 & 18 & 17 & 4 & 3 & 25 & 18 & 14 & 6 & 9 & 12 & 4 & 6 & 4 & 200 \\
\hline 8 & 3 & 3 & 6 & 16 & 13 & 14 & 18 & 13 & 10 & 11 & 18 & 16 & 11 & 13 & 11 & 8 & 9 & 7 & 200 \\
\hline 9 & 3 & 7 & 8 & 14 & 12 & 14 & 15 & 14 & 8 & 14 & 12 & 22 & 7 & 11 & 14 & 10 & 10 & 5 & 200 \\
\hline 10 & 8 & 5 & 10 & 18 & 12 & 17 & 12 & 7 & 11 & 10 & 1 & 10 & 18 & 11 & 15 & 5 & 16 & 4 & 200 \\
\hline 11 & 8 & 7 & 10 & 10 & 14 & 8 & 16 & 8 & 10 & 7 & 15 & 17 & 10 & 13 & 11 & 10 & 13 & 13 & 200 \\
\hline 12 & 4 & 1 & 5 & 18 & 13 & 9 & 15 & 9 & 8 & 7 & 9 & 16 & 17 & 9 & 25 & 13 & 14 & 8 & 200 \\
\hline 13 & 4 & 3 & 4 & 8 & 14 & 9 & 10 & 13 & 12 & 7 & 4 & 11 & 13 & 20 & 22 & 20 & 14 & 12 & 200 \\
\hline 14 & 1 & 1 & 5 & 6 & 9 & 6 & 12 & 26 & 22 & 5 & 8 & 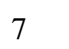 & 19 & 7 & 13 & 21 & 17 & 15 & 200 \\
\hline 15 & 1 & 1 & 3 & 10 & 11 & 5 & 10 & 25 & 27 & 4 & 9 & 4 & 16 & 8 & 15 & 18 & 11 & 22 & 200 \\
\hline 16 & 3 & 1 & 6 & 9 & 16 & 9 & 7 & 17 & 17 & 5 & 3 & 7 & 22 & 8 & 19 & 17 & 12 & 22 & 200 \\
\hline 17 & 5 & 2 & 4 & 6 & 10 & 6 & 1 & 26 & 25 & 5 & 2 & 4 & 17 & 4 & 5 & 32 & 14 & 32 & 200 \\
\hline \multirow[t]{2}{*}{18} & 26 & 0 & 5 & 2 & 7 & 1 & 5 & 20 & 21 & 1 & 4 & 2 & 21 & 1 & 3 & 28 & 11 & 42 & 200 \\
\hline & 200 & 200 & 200 & 200 & 200 & 200 & 200 & 200 & 200 & 200 & 200 & 200 & 200 & 200 & 200 & 200 & 200 & 200 & \\
\hline
\end{tabular}

In the frequency matrix in Table 2, columns exhibit the frequency of preference of the stimulants in the RVS while rows exhibit the value rankings. For instance, the frequency of participants who chose salvation as a value of high priority is 81 and the frequency of those who prefered it at the lowest priority is 26 . According to Table 2 , the first five values that the participants see of higher priority in life were respectively salvation $(f=81)$, family security $(f=25)$, a world at peace $(f=24)$, inner harmony $(f=15)$ and freedom $(f=13)$. In other words, this ranking of values is the frequency of terminal values being chosen at the first order. Moreover, the terminal values that the participants consider of lower priority and choose with the lowest scores are respectively pleasure $(f=42)$, social recognition $(f=28)$, salvation $(f=26)$, mature love $(f=21)$ and an exciting life $(f=21)$. In other words, this value ranking represents the lowest-ranked terminal values. 
Table 3

Instrumental Values Frequency Matrix

\begin{tabular}{|c|c|c|c|c|c|c|c|c|c|c|c|c|c|c|c|c|c|c|c|}
\hline & 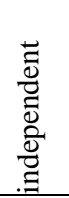 & 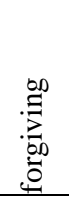 & 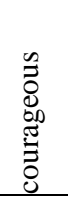 & $\begin{array}{l}\overrightarrow{\sigma_{0}} \\
\tilde{\Xi} \\
\end{array}$ & 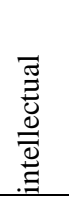 & 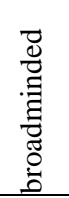 & 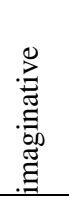 & 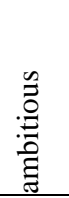 & $\begin{array}{l}\overrightarrow{0} \\
: \overrightarrow{0} \\
\overrightarrow{0} \\
0 \\
0\end{array}$ & 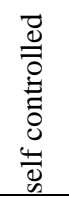 & \begin{tabular}{l}
$\stackrel{0}{0}$ \\
\hdashline \\
\hdashline
\end{tabular} & $\begin{array}{l}\overline{\mathscr{J}} \\
.00 \\
0\end{array}$ & 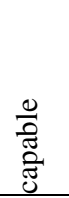 & $\begin{array}{l}\bar{E} \\
\overrightarrow{0} \\
\overline{0} \\
\bar{U}\end{array}$ & 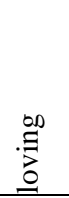 & $\begin{array}{l}\frac{0}{0} \\
\frac{0}{0} \\
0 \\
0 \\
0 \\
0\end{array}$ & $\frac{\widetilde{d}}{U}$ & $\begin{array}{l}\vec{Z} \\
\frac{2}{0} \\
\end{array}$ & $\stackrel{\vec{\pi}}{0}$ \\
\hline 1 & 49 & 6 & 13 & 40 & 9 & 6 & 7 & 3 & 2 & 6 & 2 & 9 & 3 & 10 & 3 & 22 & 4 & 6 & 200 \\
\hline 2 & 18 & 12 & 17 & 30 & 9 & 12 & 6 & 6 & 5 & 8 & 6 & 11 & 4 & 6 & 7 & 16 & 11 & 16 & 200 \\
\hline 3 & 15 & 12 & 14 & 23 & 14 & 13 & 9 & 4 & 2 & 16 & 9 & 18 & 3 & 0 & 5 & 18 & 10 & 12 & 200 \\
\hline 4 & 19 & 14 & 11 & 16 & 14 & 10 & 11 & 8 & 1 & 15 & 12 & 17 & 6 & 9 & 5 & 17 & 7 & 8 & 200 \\
\hline 5 & 9 & 6 & 10 & 17 & 8 & 12 & 5 & 10 & 2 & 16 & 11 & 20 & 9 & 6 & 12 & 16 & 17 & 14 & 200 \\
\hline 6 & 7 & 12 & 15 & 8 & 6 & 14 & 10 & 10 & 7 & 6 & 6 & 23 & 7 & 6 & 14 & 11 & 20 & 18 & 200 \\
\hline 7 & 7 & 8 & 8 & 14 & 5 & 18 & 8 & 11 & 3 & 12 & 9 & 14 & 10 & 20 & 11 & 11 & 12 & 19 & 200 \\
\hline 8 & 9 & 8 & 3 & 10 & 12 & 21 & 10 & 4 & 4 & 6 & 11 & 8 & 13 & 18 & 16 & 15 & 11 & 21 & 200 \\
\hline 9 & 5 & 6 & 17 & 2 & 9 & 13 & 15 & 6 & 2 & 8 & 16 & 6 & 10 & 14 & 14 & 18 & 19 & 20 & 200 \\
\hline 10 & 7 & 21 & 8 & 10 & 13 & 11 & 8 & 12 & 5 & 9 & 12 & 12 & 16 & 15 & 12 & 10 & 12 & 7 & 200 \\
\hline 11 & 9 & 10 & 10 & 3 & 12 & 12 & 9 & 8 & 10 & 11 & 10 & 16 & 14 & 16 & 14 & 8 & 18 & 10 & 200 \\
\hline 12 & 7 & 11 & 15 & 9 & 9 & 17 & 10 & 5 & 8 & 12 & 22 & 9 & 14 & 13 & 18 & 5 & 4 & 12 & 200 \\
\hline 13 & 5 & 10 & 13 & 4 & 16 & 9 & 20 & 12 & 6 & 18 & 11 & 10 & 14 & 6 & 16 & 8 & 11 & 11 & 200 \\
\hline 14 & 8 & 10 & 12 & 8 & 11 & 8 & 15 & 8 & 19 & 11 & 14 & 4 & 11 & 17 & 16 & 7 & 12 & 9 & 200 \\
\hline 15 & 7 & 14 & 10 & 2 & 17 & 7 & 17 & 8 & 7 & 21 & 12 & 9 & 19 & 19 & 16 & 4 & 8 & 3 & 200 \\
\hline 16 & 5 & 15 & 11 & 4 & 13 & 6 & 20 & 15 & 12 & 13 & 20 & 5 & 22 & 12 & 8 & 5 & 8 & 6 & 200 \\
\hline 17 & 11 & 13 & $J$ & 0 & 13 & 7 & 13 & 27 & 37 & 9 & 10 & 7 & 17 & 5 & 6 & 7 & 8 & 5 & 200 \\
\hline 18 & 3 & 12 & 8 & 0 & 10 & 4 & 7 & 43 & 68 & 3 & 7 & 2 & 8 & 5 & 7 & 2 & 8 & 3 & 200 \\
\hline & 200 & 200 & 200 & 200 & 200 & 200 & 200 & 200 & 200 & 200 & 200 & 200 & 200 & 200 & 200 & 200 & 200 & 200 & \\
\hline
\end{tabular}

According to Table 3, 49 of the participants chose the value of being independent with the highest priority, while three of them at the lowest priority. The first five values that the participants see of higher priority in life were respectively independent $(f=49)$, honest $(f=40)$, responsible $(f=$ $22)$, courageous $(f=13)$ and cheerful $(f=14)$. In other words, this value ranking represents the highest-ranked instrumental values. Moreover, the terminal values that the participants consider of lower priority and choose with the lowest scores were respectively obedient $(f=68)$, ambitious $(f=$ $43)$, forgiving $(f=12)$ and intellectual $(f=10)$. In other words, this value ranking represents the lowest-ranked instrumental values.

Table 4

The Scale Values and Priority Rankings of Terminal and Instrumental Valuesbased on Ranking Judgments

\begin{tabular}{lcclc}
\hline \multicolumn{1}{c}{ Terminal values } & Scale value & $\begin{array}{c}\text { Significance } \\
\text { ranking }\end{array}$ & Instrumental values & Scale value \\
\hline family security & 0.000 & 1 & honest & 0.000 \\
a world at peace & 0.359 & 2 & independent & 0.229 \\
salvation & 0.374 & 3 & responsible & 0.329 \\
inner harmony & 0.485 & 4 & logical & 0.440 \\
self-respect & 0.606 & 5 & helpful & 0.502 \\
equality & 0.673 & 6 & courageous & 0.504 \\
freedom & 0.698 & 7 & broadminded & 0.563 \\
happiness & 0.723 & 8 & clean & 0.655 \\
a sense of accomplishment & 0.792 & 9 & self-controlled & 0.711 \\
true friendship & 0.827 & 10 & cheerful & 0.769
\end{tabular}




\begin{tabular}{lllll} 
wisdom & 1.021 & 11 & forgiving & 0.770 \\
national security & 1.058 & 12 & intellectual & 0.777 \\
a comfortable life & 1.108 & 13 & loving & 0.800 \\
an exciting life & 1.385 & 14 & polite & 0.855 \\
mature love & 1.390 & 15 & imaginative & 0.876 \\
a world of beauty & 1.465 & 16 & capable & 0.996 \\
social recognition & 1.585 & 17 & ambitious & 1.133 \\
pleasure & 1.688 & 18 & obedient & 1.494 \\
\hline
\end{tabular}

When the terminal values belonging to the RVS was analyzed using the scaling technique, the most commonly (predominantly) preferred value by the teacher candidates was found to be family security. Following this value, there were respectively a world at peace, salvation, inner harmony and self-respect. The terminal value of lowest priority was the value of pleasure. Following this value, the lowest priority values were respectively social recognition, a world of beauty, mature love, and an exciting life.

When the instrumental values were analyzed using the scaling technique, the most commonly preferred/highest-ranked instrumental value was found to be honesty. Following this value, the most commonly preferred values were respectively independent, responsible, logical and helpful. The value of lowest priority, on the other hand, was found to be obedient. Following this, the values of lowest priority were found to be respectively ambitious, capable, imaginative, and polite.

\section{Discussion, Conclusion and Recommendations}

When the frequency scores of the ranked values examined the first rank and having the highest frequency score was salvation $(f=81)$; while the lowest-ranked terminal value is found to be pleasure $(f=42)$ within the terminal values. Similarly, when instrumental values were ranked on the basis of frequency, the value that was preferred at the first rank and having the highest frequency value was independent $(f=49)$, while the lowest-ranked instrumental value was found to be obedient $(f=68)$. However, when the rank order judgements scale technique was used, the values of top priority for teacher candidates were respectively family security (taking care of loved ones), a world at peace (free of war and conflict), salvation (saved, eternal life), inner harmony (freedom from inner conflict), and self-respect (self-esteem). The values of lowest priority were respectively the values of pleasure (an enjoyable leisurely life), social recognition (respect, admiration), a world of beauty (beauty of nature and the arts), mature love (sexual and spiritual intimacy), and an exciting life (a stimulating, active life). The instrumental values of top priority for teacher candidates were respectively honest, independent, responsible, logical, and helpful. The values of least priority were found to be obedient, ambitious, capable, imaginative, and polite.

Rokeach (1973) qualifies the value rankings obtained as a result of his own study as a general characteristic of the American culture and states that many of the findings of his study corresponds with Maslow's hierarchy of needs. Maslow (2001) emphasizes that person-specific needs lead to person-specific values; that the dispositional differences between individuals and the choice differences in the ways the person interacts with their own, culture and the world creates the values; and that needs and values are in a hierarchical and developmental relation in terms of power and primacy. While security is a rather strong, overbearing and vital need in comparison to love, the need for food is stronger than both of them. Furthermore, these basic needs are generally the steps taken in self-actualization as all the basic needs are. In addition to this, Maslow (1970) states that if the physiological needs are relatively well gratified, there then emerges a new set of needs, which we may categorize roughly as the safety needs (security, stability, dependency, protection, freedom from fear, from anxiety and chaos, need for structure, order, law, limits, strength in the protector, and so on). In the case that both the physiological and security needs are quite well satisfied, that the needs of love, compassion, and belonging would arise. However, the needs of security will become of top priority when there are real threats in the society for law and regulation. Within this frame, it can be said that the value of family security in the RVS being the prioritized terminal value by the teacher candidates is related to this state of affairs. According to Maslow (1970), the threat of chaos or of nihilism can be expected in most human beings to produce a regression from any higher needs to the more prepotent 
safety needs. Therefore finding the most preferred terminal values as family security and $a$ world at peace instead of higher order needs like pleasure, social recognition, a world of beauty, and mature love may relate with feeling of the threat of chaos or of nihilism. In other words, these terminal value preferences (family security and $a$ world at peace) show us that teacher candidates need security and peace not only in their daily life but also in the world. In addition to this, Rokeach (1973) in his study states that the need of security proving of lower importance for affluent and educated individuals is not due to this need being viewed of less value but because these needs are already being met, hence leading to the emphasis of values such as love, competence, and self-actualization as a result of the need for security having already been guaranteed. In addition, when considering the realities of the sample group in this study, teacher candidates mostly are still students and not working, it is not surprising to find that family security (taking care of loved ones) is prioritized. According to Kağıtçıbaşı (1996), in the societies where the financial dependency is in question, reciprocally tight relations and dependency is valued rather than independence. Similarly, according to Smith and Schwartz (1996), in conservative cultures, the person is identified with the community and participates in the communal lifestyle and largely gains meaning through societal relations. This type of value emphasizes the protection of status quo, propriety and the restriction of actions which may disarray the group of solidarity. Examples of specific values are social order, respect to tradition, family security, and self-discipline. In the cultures where independence is emphasized, the person is seen as a being who expresses their own uniqueness and endeavours to express their own internal qualities (preferences, characteristics, emotions, motives). Therefore, it can be expected that in a conservative culture, the value priority of teacher candidates will be identified with a community and be oriented towards a solidarity group. Results of the study show that the two terminal values preferred with top priority, family security and a world at peace, in this study means that the teacher candidates see social (focus on others) and society-centered values at higher priority. Within instrumental values highest priority was given to honesty and this means that values related to morality and relations are seen of higher priority. Within this frame, Kağıtçıbaşı (1996) states that those who are from the collectivist cultures identify with collectivist value judgments and behaviours while those from individualistic cultures do so with individualistic ones. Nonetheless, in the study, the teacher candidates' top five preferences among terminal values were salvation, inner harmony, and self-respect and this shows that self-focused values are prioritized. Their top preferences among instrumental values are independent and logical shows that the competence value was preferred which is rather personal than interpersonal. When the top five terminal value priorities of teacher candidates were examined, they were both related to the values that focus on others as well as personal, selffocused ones. In the instrumental values, it is seen that the preferences are both focus on morality and relations and on competence. Within this frame, it is understood that both inter-personal and personal values are important for teacher candidates.

According to Smith and Schwartz (1996), the value priorities of individuals are directly affected by the changing daily experiences of people within their ecological and socio-political context and reveal the cultural and individual processes of change. According to Ayvalıoglu's (1989) study, the terminal value priorities of Turkish university students are respectively national security, family security, salvation, a world at peace, and true friendship; the instrumental value priorities of them are respectively self-controlled, responsible, courageous, ambitious, and cheerful. The common values between Ayvalıoglu's (1989) study and this study in terminal value priorities are family security, salvation, and $a$ world at peace. In addition to this, the only common prioritized value between these two studies are responsible within the instrumental values. Çileli's (2000) study with Turkish university students in the years of 1989, 1992 and 1995 showed interesting results. In 1989, most important terminal values for Turkish university students were self-respect, freedom, inner harmony, and equality. As for the 1992 sample, the most important terminal values were wisdom, along with mature love, inner harmony, happiness, and family security. For 1995 sample, happiness, inner harmony, an exciting life, and mature love were the most important terminal values. Çileli's (2000) study showed that the four most important instrumental values for the 1989 sample were independence, honesty, broad-mindedness, and courage. The four most important instrumental values for the 1992 sample were ambition, cheerfulness, broad-mindedness, and capability. The four most important instrumental values for the 1995 sample were ambition, cheerfulness, capability and 
courage. Within this frame, it is seen that the teacher candidates' value priorities in terms of both terminal and instrumental values are different from university students' value priorities with reference to the studies conducted in the last 30 years. Therefore, this difference in the individuals' value priorities corresponds with the historical-social change of the Turkish society and reveals the culturalindividual processes of change. In addition to this, it should be taken into account that the different results in the studies conducted with university students by both Ayvalığlu (1989) and Çileli (2000) can be related to their different sample/study groups.

In Schwartz (1994) circular model of values, the most basic aspect of the theorized structure is the organization of the four higher order value types into two dimensions: Openness to change (selfdirection and stimulation) vs. conservation (tradition, conformity, security) and self-enhancement (power, achievement) vs. self-transcendence (universalism, benevolence). According to Kuşdil and Kağıtçıbaşı (2000), the dimension of conservation involves the individuals' values, which enables them to maintain consistency and definitiveness in their relations with people, institutions and traditions. The type that this dimension exhibits the least correlation, on the other hand, is hedonism. Within this frame, that the value of family security proving of highest priority and salvation proving of third highest priority for teacher candidates can be evaluated within the frame of Schwartz' dimension of the value of conservation. However, while the second and third value priorities of teacher candidates as a world at peace and inner harmony corresponds to Schwartz' dimension of the values of self-transcendence and universalism; the fifth priority self-respect corresponds to the value types of openness to change and self-direction. According to Kuşdil and Kağıtçıbaşı (2000), the value dimension of openness to change is oriented towards individuals being enabled to follow their emotional and mental interests in unpredictable ways, while the value dimension of self-transcendence is oriented towards the individual relinquishing their own egotistical purposes for the good of the humanity and the nature. Within this frame, it can be said that the value priorities which the teacher candidates preferred at the top five ranks do not only correspond with the value dimension of conservation in Schwartz' model of values but also with openness to change and self-transcendence.

Human behaviour occurs in different forms, degrees and intensity as a product of the societal structure and genetic features. Within this frame, it can both be said that human behavior occurs in a unique form as a product of the mental and emotional disposition possessed and that it is affected by the societal structure in which the individual is born and raised. Therefore, it can be spoken of that values and behavior not only arises as a product of active mental evaluations, but also as a product of external determinants. The external structure in which the individual resides are informal-formal environments. Individuals are equipped in formal educational institutions in terms of fundamental knowledge and skills. The most fundamental actor of formal educational institutions, in other respects, are teachers. The values possessed by teachers will be the determinant of the quality of the processes and products of education and training. In the literature, there are different instruments and analysing techniques for defining teacher values. RVS, the instrument used in this research, determine how the person prioritizes values rather than whether a value is possessed by a person. In the present study, scaling technique was used for analyzing the teachers' values. It is seen that value rankings differ when they are ranked on the basis of preference and when they are ranked using the scaling technique. This difference in the individuals' value priorities corresponds with the historical-social change of the Turkish society and reveals the cultural-individual processes of change. In Turkey there can be mention of that both collectivist and individualistic values are seen of high priority and a togetherness of values that represent different cultural structures. 


\section{References}

Akyıldız, H. (2018). Davranıs ilgili kavramlar, açıklamalar [Concepts and explanations related to behavior]. Ankara: Kalem Kitap.

Akyıldız, H., \& Aslan, C. (2016). Values and human behavior. In Proceedings of the $3^{\text {rd }}$ International Eurasian Educational Research Congress 31 May- 3 June 2016 (pp. 42-145). Muğla Sitk1 Koçman University, Muğla, Turkey.

Ayvalığlu, N. (1989). A comparison of Turkish and American value systems. Studies in Psychology, 17(0), 85-100.

An1l, D., \& Güler, N. (2006). An example of the scaling study by pairwise comparison method. Hacettepe University Journal of Education, 30, 30-36.

Boudon, R. (2013). The origin of values: essays in the sociology and philosophy of beliefs. New Brunswick (US) and London (UK): Transaction Publishers.

Çalışkur, A., \& Aslan, A. E. (2013). Rokeach Values Inventory reliability and validity study. Balıkesir University the Journal of Social Sciences Institute, 16(29), 81-105.

Çalışlar, A. (1997). Felsefe sözlüğ̈̈ [Philosophy dictionary]. İstanbul: Cem Publishing.

Çileli, M. (2000). Change in value orientations of Turkish youth from 1989 to 1995. The Journal of Psychology, 134(3), 297-305.

Dunn-Rankin, P., Knezek, G. A., Wallace, S., \& Zhang, S. (2004). Scaling methods. Mahwah, New Jersey: Lawrence Erlbaum Associates.

Guilford, J. P. (1954). Psychometrics methods. New York: Mc Graw-Hill Book Co.

Karasar, N. (2003). Bilimsel araştırma yöntemleri [Scientific research method]. Ankara: Nobel Publishing.

Kuşdil, E., \& Kağıtçıbaşı, Ç. (2000). Value orientations of Turkish teachers and Schwartz's theory of values running head: Values. Turkish Journal of Psychology, 15(45), 59-76.

Macionis, J. J. (2012). Sosyoloji [Sociology]. Ankara: Nobel Publishing.

Maslow, H. A. (2001). İnsan olmanın psikolojisi [Toword a psychology of being]. İstanbul: Kural Dış1 Publishing.

Maslow, H. A. (1970). Motivation and personality. New York: Harper and Row Publishers.

Neuman, W. L. (2010). Toplumsal araştırma yöntemleri [Social research methods]. İstanbul: Yayın Odasi.

Ning, H. K., Lee, D., \& Lee, W. O. (2016). The relationship between teacher value orientations and engagement in professional learning communities. Teachers and Teaching: Theory and Practice, $22(2), 235-254$.

Özkalp, E. (2005). Sosyolojiye giriş [Introduction to sociology]. Bursa: Ekin Publishing.

Rokeach, M. (1973). The nature of human values. New York: The Free Press.

Schwartz, S. H. (1994). Are there universal aspects in the structure and contents of human values? Journal of Social Issues, 50(4), 19-45.

Smith, P. B., \& Schwartz, S.H. (1996). Values. In J. W. Berry, M. H. Segall, \& C. Kagitcibasi (Eds.), Handbook of cross-culturel psychology, social behavior and applications (pp. 77-118). USA: Allyn \& Bacon.

Tasker, M., \& Packham, D. (1993). Industry and higher education: A question of values. Studies in Higher Education, 18(2), 127-136.

Tolan, B. (2005). Sosyoloji [Sociology]. Ankara: Gazi Bookstore.

Turgut, M. F., \& Baykul, Y. (1992). Ölçekleme teknikleri [Scaling techniques]. Ankara: ÖSYM Publishing. 
